\title{
Effect of Contemporaneous Exchange Rate Changes on Value of Multinational Nonfinancial Companies Listed at Nairobi Securities Exchange
}

\author{
Nebart Oguda Avutswa*, Tobias Olweny \& Oluoch Oluoch
}

School of Business \& Economics, Jomo Kenyatta University of Agriculture and Technology, Kenya

\begin{abstract}
The study investigates the effect of contemporaneous exchange rate changes on value of multinational nonfinancial companies listed at Nairobi Securities Exchange for period 2001-2016. Unexpected exchange rate changes and lagged exchange rate movements were used as control variables. The study adopted a two staged methodology. The first stage involved the determination of the foreign exchange exposure. At this point the REER is determined as the weighted average of the seven major currencies used by Kenya. The unexpected foreign exchange changes were determined using the ARIMA and GARCH model. The second stage of analysis involves a panel model where different aspects of foreign exchange exposure are regressed on firm value. The results indicated that contemporaneous exchange rate changes have a negative significant influence on the value of nonfinancial companies listed at the Nairobi Securities Exchange. The results of the study were inconclusive on the effects of lagged changes in exchange rates on firm value. The findings of the study reveal that unexpected exchange rate changes have a significant negative influence on firm value.
\end{abstract}

Key Word: Unexpected exchange rate, lagged exchange rates, contemporaneous exchange rate, firm value

\section{Background of the Study}

Exchange rate movements have been a big concern for investors, analyst, managers and shareholders since the abolishment of the fixed exchange rate system of Bretton Woods in 1971 (Afza \& Alam, 2011). This system was replaced by a floating rates system in which the price of currencies is determined by supply and demand of money (El-Masry \& Abdel-Salam, 2007). Given the frequent changes of supply and demand influenced by numerous external factors, this new system is responsible for currency fluctuations (Abor, 2005).

Corporations are exposed to the risk of changing exchange rates through many channels. For example, if a firm relies on international or cross-border sales, the firm exposes itself to the risk of foreign exchange rate fluctuations. The change in exchange rates will have an impact on the value of international sales revenue (Abor, 2011). Local companies, firms and corporations that do not have any international revenue or are not involved in cross-border sales may also be impacted by changing exchange rates, possibly indirectly through their competition with other importing companies (Jong et al., 2006). Researchers continue their efforts to understand the determinants and level of exposure to changing exchange rates for corporations because of the implications for business activity of foreign exchange risk and the difficulty in predicting fluctuations in foreign exchange markets (Salifu, Osei \& Adjasi, 2007).

Empirical research indicates that volatile exchange rates affect the revenue and profits of both multinational and local corporations. Because of the prevalence of outsourcing activities to foreign countries, corporations incur costs in foreign currency (e.g., wages, taxes and material) and it is important for corporate financial managers to be aware of the extent of this exposure (Abor, 2011). Furthermore, corporations not involved in foreign exchange trades or outsourcing activities are also exposed to the fluctuating exchange rates through competition with multinational organizations, foreign competitors, and macroeconomic conditions. 
Therefore, many local and multinational organizations find their income statements and business performance affected by fluctuating exchange rates, in spite of their having only indirect financial exposure. A change in prices, the cost of final goods, the cost of raw material, labor costs or the costs of input or output and other substitute goods due to fluctuating exchange rates may have an adverse effect on the competitive position of a local or domestic firm with no international and foreign activities. Theory and empirical work in financial economics suggests that the exposure of a firm to changing exchange rates depends on the type of product and the nature of the competitive environment in which the firm operates (Bradley \& Moles, 2001).

Foreign exchange risk is a major concern for investors and managers alike. One of the difficulties in managing foreign exchange risk - whether from an investor's or a manager's point of view - is measuring the extent to which companies are exposed to the risk. Fundamentally addressing the problem of measuring exchange rate operating exposure involves analyzing the competitive position of the specific company, the dynamics of that company, as well as the dynamics of the markets in which the company is involved. A shortcut to the measurement problem may be to exploit the information content in the stock prices (Afza \& Alam, 2011).

\section{Literature Review}

Contemporaneous exchange rate changes refers to the current (spontaneous) changes in exchange rate (Atindehou \& Gueyie, 2001). The movements in foreign exchange rates can be measured in nominal and real terms (El-Masry, 2006). Atindehou and Gueyie (2001) claim that there is little difference between nominal and real exchange rates because they are highly correlated. Thus, if the changes for nominal and real exchange rates were almost perfectly correlated, then the use of either one would have similar impact on stock returns. Frait and Komareck, (2001) found that contemporaneous movements in nominal and real foreign exchange rates are almost perfectly correlated for the seven countries used in his study. This study uses the real effective exchange rate as generated to determine the contemporaneous changes across the periods.

Several empirical studies have examined how firms deal with foreign exchange risk and the effect on their financial performance. Belk (2010), confirmed the existence of a positive and significant relation between the use of currency derivatives and firm value for a sample of UK firms. Similar result was found by Carter, Rogers, and Simkins (2006), where the study showed that hedging with relation to oil prices in the airlines industry is positively related to firm value and the hedging premium reaches over 5\%. The authors showed evidence that the greatest benefit of hedging in this sector would be the reduction in underinvestment costs because the fuel price is highly correlated to the investment opportunities in the sector. Du (2010) in his study on exchange rate matters and asset pricing, concluded that whether firms need to hedge the currency risk depends on whether currency exposure is positive or negative. He argued that firms with positive exposure should hedge the risk to reduce the cost of capital, while firms with negative exposure should not.

Takatoshi (2013) investigated the effect of exchange rate risk management on the exchange rate exposure of Japanese firms. They noted that firms with larger dependency on foreign markets have larger foreign exchange exposure and that the higher the U.S. dollar invoicing share, the larger the foreign exchange exposure. In addition, they found out that local currency (Yen) invoicing itself reduces the foreign exchange exposure. Their findings indicated that Japanese firms utilized operational and financial hedging strategies and price revision policy depending on their choice of invoicing currency.

El-Masry (2006) studied the foreign exchange rate exposure of UK nonfinancial companies (364) at the industry level over the period 1981-2001. The study considered the impact of the changes (actual and unexpected) in exchange rates on firms' or industries' stock returns employing OLS model. The findings indicated that a higher percentage of UK industries were exposed to contemporaneous exchange rate changes than those reported in previous studies. The study provides important insight thought it would important to determine whether similar results would be found in case of developing financial markets like Kenya. 
Lee and Suh (2012) used a sample of 261 US multinationals over the period 1984-2002 to examine the relation between exchange rate changes and the profitability of foreign operations. The study found that the impact of exchange rate changes on foreign operations' profitability is not statistically significant in the majority of industries. Furthermore, exchange rate changes explained less than $2 \%$ of the variation in foreign operations' profitability for most industries. The study also found that the impact of exchange rate changes on foreign operations' profitability is generally weak for non-US multinationals from Australia, Canada, Japan and the UK. The study used trade-weighted exchange rates as opposed to the contemporaneous exchange rate changes. A replication of the study using contemporaneous exchange rate changes would reveal the dynamic relations between exchange rates and firm performance.

Mozumder, De Vita, Larkin, and Kyaw (2015), investigated the sensitivity of firm value to exchange rate (ER) movements, and the determinants of such exposure for 100 European blue chip companies over 20012012. The study unveiled a positive relationship between ER movements and the market value of firms, indicating that a depreciation of ERs (indirect quotation) is likely to have a positive impact on the market value of European firms. The relationship between exposure and firm-specific characteristics was found to be weak, though smaller-sized firms were found to be slightly more exposed to ER movements than larger ones. The shortcoming of the shortcoming of the study was overreliance on Eurozone countries with the UK as the only non-Eurozone country included in the analysis.

\section{Methodology}

The population for the current study constituted the 19 multinational nonfinancial companies listed at the Nairobi Securities Exchange. Multinational firms engage in a many foreign currencies denominated transactions which subject their cash flows to foreign exchange exposures. The study used secondary data with two data sets for a 16 year period from 2001 to 2016. Data on monthly share prices was sourced from NSE monthly reports whereas the average monthly exchange rates were sourced from Central Bank of Kenya.

Contemporaneous exchange rates were computed for every month in the period of study as the current changes in the real effective exchange rates. The real effective exchange rate (REER) is computed as weighted average of the different real exchange rates (RER) from the basket of currencies where the weights are determined on importance of the country based on the terms of trade between the countries.

Seven major currencies were selected to constitute the basket from which the foreign currency exchange rates are determined. This includes; US Dollar, Euro, Sterling Pound, Japanese Yen, South African Rand, Tanzanian Shillings and Ugandan Shillings. The currencies were selected since they constitute Kenya's largest foreign exchange volumes. The formula used for the computation of the real exchange rates (RER) from the NER in the study is given by;

$$
R E R=N E R \times \frac{p^{*}}{p}
$$

Where $p^{*}$ is the price levels of the foreign currency $p$ the price level of the domestic currency and NER the nominal exchange rate. Further the study adopted the formula constructed by Broeck and Slok (2001) for real exchange rates from relative prices and nominal exchange rates by the real exchange rate decomposition;

$q_{t}=s_{t}-p_{t}^{*}+p_{t}$

Where $q_{t}$ is the real exchange rate, $s_{t}$ the nominal exchange rate, $p_{t}^{*}$ the foreign country's price levels $p_{t}$ the domestic country's price levels all in natural logarithms.

With the natural logarithms of the individual from the individual decomposed RERs, the resulting equation adopted to compute the REER that was adopted was an arithmetic weighted average of the individual logged RERs of a basket of currencies. 
$R E E R=\sum_{i=1}^{m} W_{i} \times \operatorname{rer}_{i}$

Where $\operatorname{rer}_{i}=\log _{e} R E R_{i}$ is the natural $\log$ of the real effective exchange rate of currency $i$

$W_{i}$ is the weight given to the currency $i$ which is determined by trading volumes.

Unexpected changes in exchange rates and lagged exchange rate exposure were used as control variables. To identify the unexpected changes in exchange rates the study fitted a time series model for the REER using the Autoregressive Integrated Moving Average (ARIMA) According to El-Masry (2006), ARIMA models are used to extract unexpected changes in exchange rates from the series of exchange rate (or interest rates) movements. However, ARIMA models as first modelled for the data are not characterised as robust for the volatility that is attributed with conditional heteroscedasticity and autocorrelation of the disturbance term. Consequently the Generalized Autoregressive Conditional Heteroscedasticity (GARCH) models is used. The fitted values of the model correspond to the expected changes in exchange rate risk factor. The residuals are then defined as the unanticipated changes in exchange rates. The study uses a one month lag of contemporaneous exchange rate changes as a proxy for lagged changes in exchange rates. The second stage of analysis involved a panel model where different aspects of foreign exchange exposure were regressed on firm value.

\section{Findings and discussions}

Table 4.1 presents the descriptive statistics of the individual exchange rates for each currency for the entire period combined. The results show very varying figures on the mean nominal exchange rates between Kenya shillings and each of the currencies. This shows that Kenya trades highly with countries with both strong currencies and weak currencies. Five of the currencies considered in the basket were all stronger than the Kenya shilling, the Sterling Poundbeing the strongest that had a mean NER of 132.460. The other two currencies in the basket that were on the other hand found to be on average weaker than the Kenya shilling were the Tanzanian shillings and the Ugandan shillings with mean NERs of 0.061 and 0.038 respectively.

The strong currencies in the basket that were trading with Kenya are globally strong and very marketable currencies globally such as the dollar that had a mean NER of 81.566 against the Kenya shilling over the 190 months combined. The weaker currencies on the other had were regional currencies that trade with Kenya by virtue of regional trade and being neighbouring countries to Kenya. The coefficient of variations indicated that Japanese Yen and Tanzanian shillings had the highest spread (20\%) over the study period with Sterling pound depicting the lowest spread (8\%) indicating that it is the most stable of the selected currencies. Madura (2011) argues that foreign exchange rate movements tend to be larger for longer time horizons thus the longer the time horizon the higher the spread.

Table 4.1: Nominal Exchange Rates Summary Statistics

\begin{tabular}{|llllll|}
\hline Currency & Mean & Std Deviation & Min & Maximum & C.V \\
\hline Euro & 100.133 & 14.896 & 66.458 & 132.94 & $15 \%$ \\
US Dollar & 81.566 & 8.929 & 64.631 & 102.606 & $11 \%$ \\
Sterling Pound & 132.46 & 11.087 & 110.742 & 156.914 & $8 \%$ \\
Japanese Yen & 78.964 & 15.621 & 58.529 & 123.189 & $20 \%$ \\
SA Rand & 9.664 & 1.788 & 6.226 & 17.396 & $19 \%$ \\
Tanzanian Shillings & 0.061 & 0.012 & 0.046 & 0.098 & $20 \%$ \\
Ugandan Shillings & 0.038 & 0.005 & 0.028 & 0.047 & $13 \%$ \\
\hline
\end{tabular}

A further analysis of the nominal exchange rates (NER) shows that the NER is very heterogeneous across the different currencies. As shown on the spaghetti plot in figure 1 of the different currencies in one graph, some of the currencies have high NERs like the Sterling Pound that is constantly above the others and above 
100 while the others like the Ugandan shilling and the Tanzanian shilling are barely above 0 throughout the period.

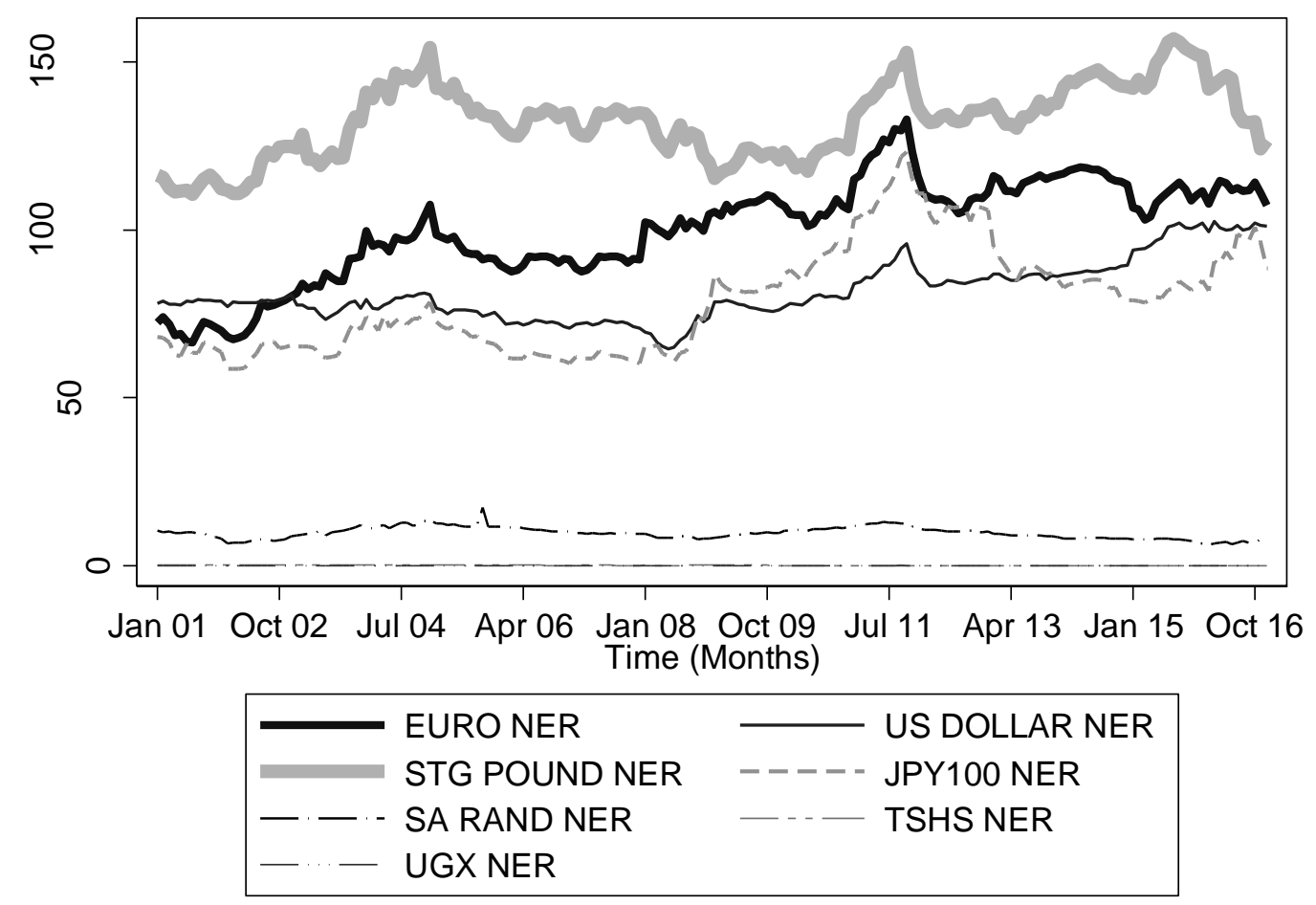

Figure 1: NER Spaghetti plot

To further examine the level of heterogeneity of the shows the level of heterogeneity of the NER an analysis of the overall mean NER with the variations within groups and between the groups of currencies was done. Table 2 shows that the mean overall NER for all the currencies and all the months in the period combines was 57.555. The overall standard deviation which is a measure of dispersion is 50.776. The overall standard deviation is very high but it is ac contribution from the variation between and variation within groups. The variation within groups of currencies was only 9.744 while the variation between the groups was 53.799. This confirms that the variation of NER between currencies is very high.

Table 2: Overall Nominal Exchange Rate (NER)

\begin{tabular}{|c|c|c|c|c|c|c|c|}
\hline \multicolumn{3}{|l|}{ Variable } & \multirow{2}{*}{$\frac{\text { Mean }}{57.555}$} & \multirow{2}{*}{$\begin{array}{l}\text { Std. Dev. } \\
50.776\end{array}$} & \multirow{2}{*}{$\frac{\text { Min }}{0.028}$} & \multirow{2}{*}{$\frac{\text { Max }}{156.914}$} & \multirow{2}{*}{$\begin{array}{l}\text { Observations } \\
\mathrm{N}=1344\end{array}$} \\
\hline Nominal & exchange & overall & & & & & \\
\hline & & between & & 53.799 & 0.038 & 132.460 & $\mathrm{n}=7$ \\
\hline & & within & & 9.774 & 23.880 & 101.781 & $\mathrm{~T}=192$ \\
\hline
\end{tabular}

Contemporaneous exchange rates were computed for every month in the period of study as the current changes in the effective exchange rate measures. The real effective exchange rate as generated was used to determine the contemporaneous changes across the periods as used in the study. Table 34.7 shows the summary statistics of the contemporaneous changes in the exchange rates. The mean movement based on the contemporaneous changes was found to be -0.002 with a standard deviation of 0.016 . This shows that evidence of fluctuating changes both negative and positive.

Table 3: Summary Statistics for Contemporaneous Changes in Exchange Rates 


\begin{tabular}{|lllll|}
\hline & Mean & Std Deviation & Min & Maximum \\
\hline Contemporaneous movements & -0.002 & 0.061 & -0.199 & 0.291 \\
\hline
\end{tabular}

Figure 2 shows the graphical presentation of the calculated changes in the exchange rates with time. The plot shows that the changes were fluctuating about zero across the period both in the negative and positive directions.

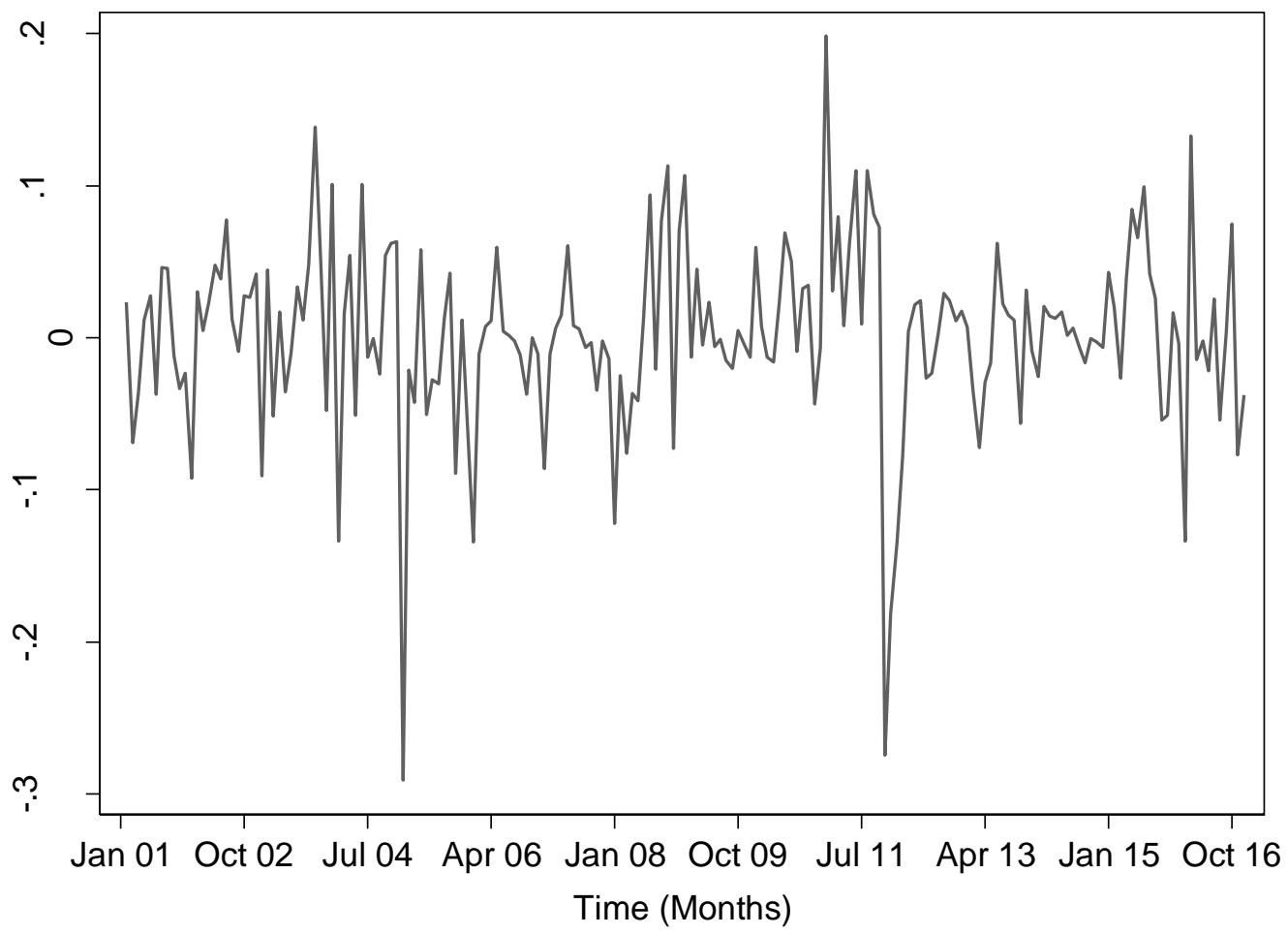

Figure 2: Contemporaneous Changes in Exchange Rates with Time

Considering that the objective was to determine the effect of contemporaneous exchange rate changes on firm value of nonfinancial companies at Nairobi Securities Exchange, the contemporaneous changes were included in the panel dataset of the 19 companies of NSE. Table 4 shows the overall summary statistics of the contemporaneous changes in the panel dataset. The overall mean was found to be -0.002 with an overall standard deviation of 0.061 . The overall variation is however equal to the variation within the groups of NSE listed companies as shown by the equal standard deviations. There is no variation between the firms themselves as implied by the standard deviation of 0 between the groups. The 0 variation between the firms can be attributed to the fact that foreign exchange rate is an exogenous variable index that is not pegged to each firm but is based on currency measurements that are similarly used by all the firms and the entire country collectively. This means that the level of effect and influence of the changes could vary across firms but the value of currency changes and currency exchange rate change measurements do not vary but are similar to all firms.

Table 4 Contemporaneous Changes Panel Analysis Statistics Summary.

\begin{tabular}{|lllllll|}
\hline Variable & & Mean & Std. Dev. & Min & Max & Observations \\
\hline Contemporaneous & overall & -0.002 & 0.061 & -0.199 & 0.291 & $\mathrm{~N}=3591$ \\
movements & between & & 0.000 & 0.021 & 0.021 & $\mathrm{n}=19$ \\
& within & & 0.061 & -0.199 & 0.291 & $\mathrm{~T}=189$ \\
\hline
\end{tabular}


The study carried out the pre-estimation diagnostic tests. The Breusch Pagan Lagrange Multiplier test was also done as a model specification test for the multiple joint influences of the independent variables on firm value It indicates that there were no significant differences on firm value cross the entity securities and therefore the random effects model is expected yield the same results as the pooled OLS model. The Hausman specification test was then used to determine the appropriate and more viable model of the random effect and the fixed effect. Based on the results of the Hausman model specification test results that favoured the random effect model, Table 5 presents the summary statistics for the random effect model of the joint effect on firm value. The results indicate that contemporaneous changes in exchange rates have a significance influence on firm value.

Table 5: RE Model Coefficients Table for the Joint Effect

\begin{tabular}{|lllll|}
\hline & Coefficients. & Std. Err. & $\mathbf{z}$ & $\mathbf{P}>|\mathbf{z}|$ \\
\hline Contemporaneous changes & -5.763 & 1.442 & -4.000 & 0.000 \\
Unexpected changes & -30.547 & 3.926 & -7.780 & 0.000 \\
Lagged changes & 1.231 & 1.227 & 1.000 & 0.316 \\
Constant & 1.214 & 0.178 & 6.830 & 0.000 \\
sigma_u & 0.000 & & & \\
sigma_e & 10.435 & & \\
Rho & 0.000 & (fraction of variance due to u_i) & \\
\hline
\end{tabular}

Post estimation diagnostic Wooldrige test was used as a test for serial correlation and the p-value of the fstatistic was found to be 0.0007 which is less than 0.05 implying the existence of first order autocorrelation of the error term. This implicatied that the fitted model violated the assumption of non-autocorrelation of the error term. A Wald test of homoscedasticity was done to test for group wise heteroscedasticity using a chisquare statistic. The results showed presence of heteroscedasticity and violation of group wise homoscedastic error terms. The normality test used the Jacque Bera approach. The p-values of the chisquare statistics for both $\mathrm{u}$ and e were found to be less than $0.05(\mathrm{p}=0.000)$ implying that the error terms do not follow a normal distribution. Breusch-Pagan Lagrangian multiplier test for cross-sectional independence gave a p-value for the chi-square as 0.000 which is less than 0.05 implying presence of cross-sectional dependence.

The random effect model fitted violated all the classical assumptions tested of cross sectional independence, non-serial correlation, normality and panel homoscedasticity of the residuals. The study therefore used GLS. A panel GLS model that allows for auto correlated and heteroscedastic errors and cross sectional dependence was then fitted to ensure the model fitted was heteroscedastic robust and allowed for serial correlation and correctional dependence.Bootstrapped standard errors were used on the FGLS model due to the violation of normality in the random effect model fitted. The results are presented in table

From the GLS model fitted, the p-value of the z-statistic for the estimated coefficient of contemporaneous exchange rate changes is 0.000 which is less than 0.05 . The null hypothesis was rejected at 0.05 level of significance and a conclusion drawn that contemporaneous exchange rate changes has a significant negative influence on firm value of multinational nonfinancial companies listed at Nairobi Securities Exchange. The results depict that that the higher the contemporaneous exchange rate changes, the lower the firms value in the market. This depicts that contemporaneous exchange rate changes erodes shareholders' funds and gives a solid ground for hedging.

The results are consistent to earlier studies. Doukas, Hall and Lang, 2003) found a significant relation between contemporaneous stock returns and unanticipated yen fluctuations. Williamson (2001) shows that firms have a higher foreign exchange rate exposure if they have higher levels of foreign sales. Bartram and Karolyi (2006) find that the foreign exchange rate exposure of firms is systematically related to the fraction of firm's foreign sales. It therefore follows that, unless hedging is used to counter the exchange rate exposures, firms with high foreign sales will have their value eroded. 


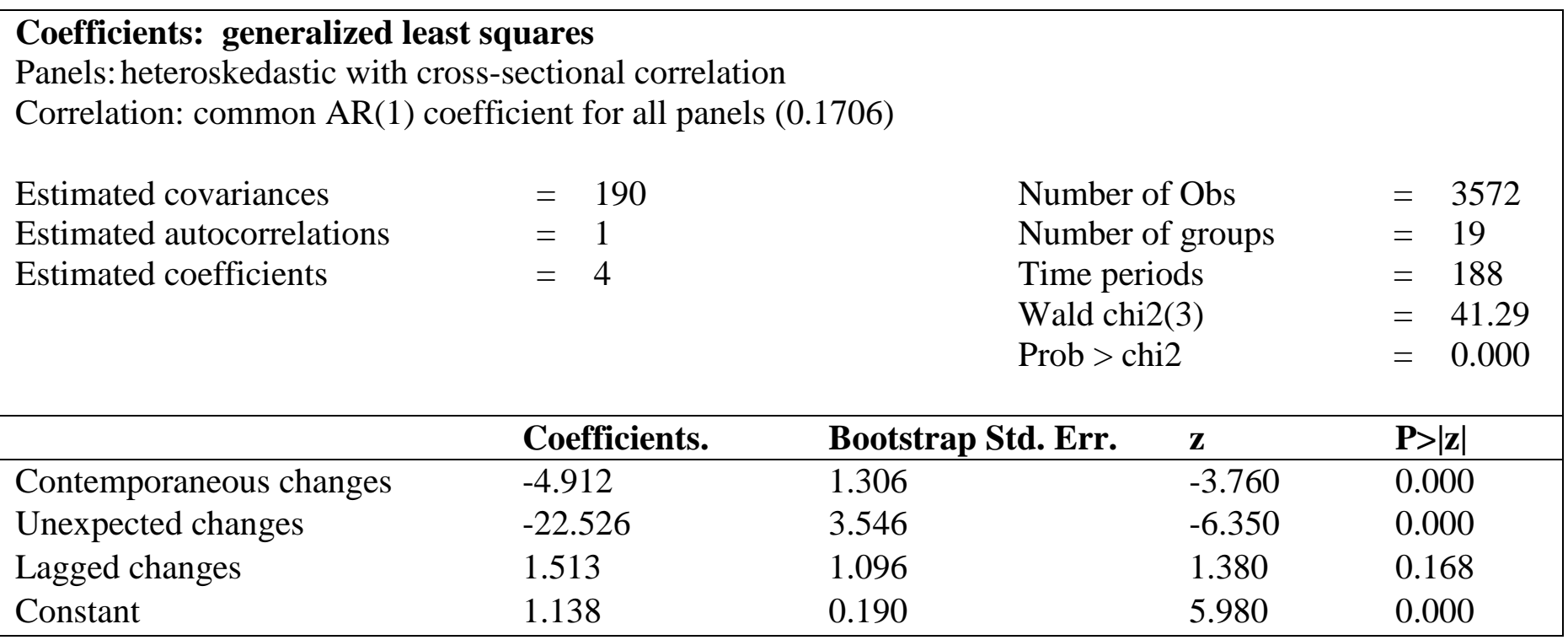

\section{Conclusion and recommendation}

The objective of the study was to determine the effects of contemporaneous changes in exchange rates on firm value of companies listed at the Nairobi Securities Exchange. The study concluded that contemporaneous exchange rate changes have a negative significant influence on the value of nonfinancial companies listed at the Nairobi Securities Exchange. The results depict that that the higher the contemporaneous exchange rate changes, the lower the firms value in the market. This depicts that contemporaneous exchange rate changes erodes shareholders' funds and gives a solid ground for hedging. Companies listed at should consider exchange rate exposure when making decisions involving share prices for floatation of shares and valuation reporting. Exchange rate exposure has been deduced to have an influence on the firm values in terms of share prices and capital gains.

\section{References}

[1] Abor, J. (2005). Managing foreign exchange risk among Ghanaian firms. The Journal of Risk and Finance. 6, 306-18.

[2] Abor, P. (2011). The pricing of exchange rate risk in stock market. Journal of Financial and Quantitative Analysis, 26.

[3] Afza, T., \& Alam, A. (2011). Corporate derivatives and foreign exchange risk management: A case study of non-financial firms of Pakistan. The Journal of Risk Finance, 12(5). 409-420. https://doi.org/10.1108/15265941111176145

[4] Aggarwal, R., \& Harper, J.T., (2010). Foreign exchange exposure of "domestic" corporations, Journal of International Money and Finance 29, 1619-1636.

[5] Agung, I. (2009). Time series data analysis using EViews. Singapore: John Wiley \& Sons (Asia) Pte Ltd.

[6] Agyei-Ampomah, S., Mazouz, K. \& Yin, S. (2013). "The foreign exchange exposure of UK nonfinancial firms: a comparison of market-based methodologies", International Review of Financial Analysis, Vol. 29, September, pp. 251-260.

[7] Belk, A, (2002).The organisation of foreign exchange risk management: A three-country study. Managerial Finance, 28, 43-52.

[8] Belk, A., \& Edelshain, D., (1997). Foreign Exchange Risk Management: The Paradox. Managerial Finance, 23, 5-24.

[9] Bradley, K., \& Moles, P. (2001). The effects of exchange rate movements on non-financial UK firms. International Business Review, 10, 51-69. 
[10] Bradley, K., \& Moles, P. (2002). Managing strategic exchange rate exposures: Evidence from UK firms. Managerial Finance 28, 28-42.

[11] Branson, W. H. (1968). Financial Capital Flows in the US Balance of Payments, North Holland Publishing Co., Amsterdam, Netherlands.

[12] Brigham, E. F. \& L.C. Gapenski. 2006. Intermediate Financial Management. $7^{\text {th }}$ edition. SeaHarbor Drive: The Dryden Press.

[13] Broll, U., \& Eckwert, B. (1999). Exchange Rate Volatility and International Trade, Southern Economic Journal, 66(1). 178-185.

[14] Brooks, C. (2008). Introductory econometrics for finance ( $2^{\text {nd }}$ ed.). New York: Cambridge University Press.

[15] Byrman, A. (2012). Social Research Methods ( $4^{\text {th }}$ ed.). New York: Oxford University Press Inc.

[16] Caballero, R. J, (1991). On the Sign of the Investment-Uncertainty Relationship. American Economic Association, Vol. 81(1). Pp.279-88.

[17] Caballero, R. J., \& Corbo, V. (1989). The Effect of Real Exchange Uncertainty on Exports: Empirical Evidence. World Bank Economic Review, 3, 263-278.

[18] Cameron, S. (2005). Econometrics, London: McGraw-Hill.

[19] Canzoneri, M.B., Clark, P. B., Glaessner, T. C. \& Leahy, M. P. (1984). The Effects of Exchange Rate Variability on Output and Employment. International Finance Discussion Papers, 240.

[20] Caporale, G.M., Pittis, N. \& Spagnolo, N. (2002). Testing for causality-in-variance: an application to the East Asian markets. International Journal of Finance \& Economics, Vol. 7 No. 3, pp. 235-45.

[21] Carbaugh, J. R. (2003). International Economics (9 $9^{\text {th }}$ ed.). Chapter 14, pp.416-36.

[22] Carter, A.D., D.A. Rogers, and B. Simkins, (2006), Does Hedging Affect Firm Value? Evidence from US Airline Industry. Financial Management, 35, 53-86

[23] Cassel, G. (1918). Abnormal deviations in international exchanges. The Economic Journal, 28(112), 413-415.

[24] Central Bank of Kenya (CBK). (2002). Monthly Economic Review, December, 2002, research Department, Central Bank of Kenya, Nairobi.

[25] Chaio, C., Hung K., \& Nwanna, G. (2001). The impact of market liberalization on firms' exchange rate exposure. Competitiveness Review, 11, 40-52.

[26] Chan, K. C., Seow, G. S., \& Tam, K. (2002). Foreign exchange risk and firm value: An analysis of US pharmaceutical firms. Managerial Finance, 28(3), 57-72.

[27] Chang, Y., (2002). The pricing of foreign exchange risk around the Asian financial crisis: evidence from Taiwan's stock market. Journal of Multinational Financial Management, 12, 223-238.

[28] Chen, J., Naylor, M. \& Lu, X. (2004). Some insights into the foreign exchange pricing puzzle: evidence from a small open economy. Pacific-Basin Finance Journal, 12(1), 41-64.

[29] Collier, A., Davis, W., Coates, J., \& Longden, S. (1992). Policies employed in the management of currency risk: A case study analysis of U.S. and UK, Managerial Finance 18, 41-51.

[30] Eiteman, T. (2006). Foreign Exchange Risk Management Practices and Products Used by Australian Firms. Journal of International Business Studies, 24, 557-573.

[31] El-Masry, A. (2006). The exchange rate exposure of UK nonfinancial companies: industry level analysis. Managerial Finance, 32(2). 115-136. https://doi.org/10.1108/0307435061064190

[32] El-Masry, A., \& Abdel-Salam, O. (2007). Exchange rate exposure: do size and foreign operations matter? Managerial Finance, 33(9). 741-765. https://doi.org/10.1108/03074350710776262

[33] Engle, F. (1982). Autoregressive Conditional Heteroskedasticity with Estimates of the Variance of United Kingdom Inflation. Econometrica, 50, (4) 987-1007.

[34] Ethier, W. (1973). International Trade and the Forward Exchange Market, American Economic Review, 63, 494-503.

[35] Faff, R.W., \& Marshall, A. (2002). The choice of foreign exchange hedging techniques: An international study, in J. Batten, and T. Fetherston, eds.: Financial Risk and Financial Risk Management (Elsevier Science, Oxford, UK).

[36] Fama, E. (2008). Agency Problems and the Theory of the Firm. Journal of Political Economy, 88, 288-307. 
[37] Fang, H., \& Loo, J.C. (1994). Dollar value and stock returns. International Review of Economics and Finance, 3, 221-231.

[38] Farrell, V.S., DeRosa D. A., \& McCown, T.A. (1983). Effects of Exchange Rate. Variability on International Trade and other Economic Variables: A Review of the Literature, Staff Studies, No. 130, U.S. Board of Governors of tile Fodera' Reserve System, USA: http://ideas.repec.org/p/sce/scecfl/85.html.

[39] Frait, J. \& Komareck, L. (2001). Real Exchange Rate Trends in Transmittal Countries, Warwick Economic Research Paper No. 596.

[40] Jorion, P. (1990). The exchange-rate exposure of US multinationals. Journal of Business, 63, 331345.

[41] Joseph, N.L., (1999). Do UK multinationals tactically use hedging techniques, Derivatives use, Trading and Regulation 5, 167-182.

[42] Krishnamoorthy, A., (2001). The impact of industrial structure and the exchange-rate exposure of industry portfolio returns, Global Finance Journal 12, 285-297.

[43] Lee, B. S., \& Suh, J. (2012). Exchange rate changes and the operating performance of multinationals. European Financial Management, 18(1), 88-116.

[44] Montiel, P.J. (1999). Determinants of the long run Real Exchange Rate; Conceptual issues and Empirical Research.

[45] Mozumder, N., De Vita, G., Larkin, C., Kyaw, S. (2015). Exchange rate movements and firm value: Evidence from European firms across the financial crisis period. Journal Economic Integration, 32(1) 112-159

[46] Salifu, Z., Osei, K., \& Adjasi, C. (2007). Foreign exchange risk exposure of listed companies in Ghana. The Journal of Risk Finance, 8 (4). 380-393, https://doi.org/10.1108/15265940710777324

[47] Smyth, R., \& Nandha, M. (2003). Bivariate causality between exchange rates and stock prices in South Asia. Applied Economics Letters, 10(11), 699-704. 